\title{
Carbonate clumped isotope thermometry in deep time: Insights from Early Triassic brachiopods and bulk carbonates
}

\author{
O. EDWARD ${ }^{1 *}$, Z. LuZ ${ }^{1}$, H. BUCHER ${ }^{2}$, T. VENNEMANN ${ }^{1}$ \\ ${ }^{1}$ Institute of Earth Surface Dynamics, Géopolis, University of \\ Lausanne, CH-1015, Switzerland (*correspondence: \\ oluwaseun.edward@unil.ch) \\ ${ }^{2}$ Paläontologisches Institut der Universität Zürich, Karl \\ Schmid-Strasse 4, 8006 Zürich, Switzerland \\ (hugo.fr.bucher@pim.uzh.ch)
}

Carbonate clumped isotope thermometry is a promising tool for palaeoenvironmental investigations because it allows for estimates of absolute temperatures of crystallisation independent of the isotopic composition of seawater. Recently, the utility of this technique for estimating seawater temperature and isotopic composition in deep time has been demonstrated [1, 2]. In the current study, absolute temperature estimates from different sites on individual fossil rhynchonelliform brachiopods as well as bulk carbonates from Early Triassic carbonate successions deposited in the Neotethys have been investigated. Results suggest that sampling along individual brachiopod growth lines represents the best strategy to obtain clumped isotope temperatures recorded by individual fossil brachiopod samples. Estimated clumped isotope temperatures for brachiopods suggests that the Early Triassic was characterized by seawater temperatures in the equatorial realms that were within the range of modern equatorial sea surface temperatures $\left(27\right.$ to $\left.32{ }^{\circ} \mathrm{C}\right)$ [3]. Furthermore, calculated water $\delta^{18} \mathrm{O}$ values for samples collected along growth lines are between $-0.9 \%$ and $+1.4 \%$, similar to the range of the $\delta^{18} \mathrm{O}$ values of modern seawater [4]. Bulk rock carbonates give higher clumped isotope temperatures $\left(41\right.$ to $90{ }^{\circ} \mathrm{C}$ ) and higher calculated water $\delta^{18} \mathrm{O}$ values, similar to those measured for bulk brachiopod shell fragments. In general, high clumped isotope temperatures correspond to high $\delta^{18} \mathrm{O}$ values calculated for water in both bulk rock and brachiopods, supporting diagenesis in a rockbuffered system in the presence of seawater. The results suggest that the oxygen isotope composition of Early Triassic seawater was about $-1 \%$, congruent with recent indications that seawater $\delta^{18} \mathrm{O}$ values remained relatively constant throughout the Phanerozoic.

[1] Bernasconi, Stefano M., et al. (2018) Geochemistry, Geophysics, Geosystems 19.9, 2895-2914. [2] Bergmann et al. (2018) Geochimica et Cosmochimica Acta 224, 18-41. [3] Trotter et al. (2008) Science 321 (5888), 550-554. [4] Grossman (2012) The Paleontology Society Papers 18, 3968. 